\title{
Etnomatematika Pada Candi Selogending Di Desa Kandangan Sebagai Sumber Belajar Matematika Kelas IV Sekolah Dasar
}

\author{
Riski Ainurriza \\ Universitas Jember \\ riski@gmail.com \\ Titik Sugiarti \\ Universitas Jember \\ titiksugiarti.fkip@unej.ac.id \\ Fajar Surya Hutama \\ Universitas Jember \\ fajarsurya.fkip@unej.ac.id
}

\begin{abstract}
Innovations to enrich mathematics learning resources can be expressed in the form of culture-based or ethnomatematic learning. The purpose of this study was to analyze the ethnomatematic content of Selogending Temple in Kandangan as mathematics teaching material for grade 4 elementary school students. This type of research uses qualitative research. Sources of research data are Selogending Temple and resource persons related to the Selogending Temple site. This study uses data collection methods in the form of observation, interviews, and documentation. Qualitative data analysis techniques used are reduction and data exposure, and drawing conclusions. Based on the results of the study, it can be concluded that there are mathematical elements in Selogending Temple including plane geometry, spatial geometry and reflection. The Selogending Temple building which has ethnomatic content is the Entrance Gate, Mbah Tejo Kusumo Petilasan, Mbah Pukulun Petilasan, Patrapan Hall, shrine, Padma, Wadung Prabu, Linggasiwa, and Mbah Raden Selogending Petilasan.
\end{abstract}

Keywords: Ethnomatematics; Selogending Temple; Mathematics Learning Resources 


\begin{abstract}
Abstrak
Inovasi untuk memperkaya sumber belajar matematika dapat dituangkan dalam bentuk pembelajaran berbasis kebudayaan atau etnomatematika. Tujuan penelitian ini adalah menganalisis muatan etnomatematika pada Candi Selogending di Kandangan, Kabupaten Lumajang, Provinsi Jawa Timur sebagai bahan ajar matematika kelas 4 SD. Jenis penelitian ini menggunakan penelitian kualitatif. Sumber data penelitian adalah Candi Selogending dan narasumber terkait situs Candi Selogending. Penelitian ini menggunakan metode pengumpulan data berupa observasi, wawancara, dan dokumentasi. Teknik analisis data kualitatif yang digunakan yaitu reduksi dan pemaparan data, serta penarikan kesimpulan. Berdasarkan hasil penelitian dapat disimpulkan bahwa terdapat unsur matematika pada Candi Selogending meliputi bangun geometri bidang, geometri ruang dan pencerminan. Bangunan Candi Selogending memiliki yang memiliki muatan etnomatematika adalah Gapura Pintu Masuk, Petilasan Mbah Tejo Kusumo, Petilasan Mbah Pukulun, Balai Patrapan, tempat pemujaan, Padma, Wadung Prabu, Linggasiwa, dan Petilasan Mbah Raden Selogending.
\end{abstract}

\title{
Kata Kunci: Etnomatematika; Candi Selogending; Sumber Belajar Matematika
}

\section{PENDAHULUAN}

Salah satu kebutuhan di Indonesia yang hasrus dipenuhi adalah pendidikan. Bagi sebagian orang menganggap pendidikan sangat penting untuk menambah pengetahuan dan siap menghadapi kemajuan teknologi saat ini. Sikap yang harus dilakukan untuk menghadapi kemajuan teknologi dengan cara menuangkan ide dan pikiran yang kreatif agar dapat memecahkan suatu masalah dengan kritis. Pendidikan juga didapatkan di sekolah yang bertujuan membangun karakter individu yang baik, sehingga menjadi contoh perilaku pelajar yang bermartabat. Sekolah mewadahi setiap orang yang ingin menempuh pendidikan secara formal dengan disediakan sarana dan prasarana yang cukup serta tenaga pendidik dan kependidikan profesional. Pendidikan di sekolah dapat dimanfaatkan untuk menerima pengetahuan baru serta mengembangkan kemampuan dengan mengikuti kegiatan-kegiatan di sekolah. Sebagai warga negara Indonesia (WNI) sudah 
seharusnya generasi muda mengembangkan kemampuan dan potensi yang dimiliki melalui pendidikan. Pendidikan sangatlah penting karena memiliki hubungan dengan kehidupan sosial masyarakat, dengan salah satunya yaitu matematika.

Matematika adalah suatu ilmu pengetahuan yang digunakan dalam bidang ilmu lainnya serta berbagai perkembangan teknologi, sehingga matematika menjadi mata pelajaran yang harus dipelajari di sekolah. Matematika identik dengan angka-angka serta operasi hitung bilangan. Materi yang diajarkan matematika sangat luas, tetapi dapat juga dikaitkan dengan hal-hal ilmiah. Matematika juga disebut sebagai mata pelajaran yang abstrak, karena bahasan yang dipaparkan menggunakan variabel, sehingga sulit dipahami oleh siswa. Banyak siswa yang mengeluh sulitnya memahami dan mempelajari matematika. Salah satu faktornya disebabkan oleh hafalan rumus, mengkontruksi rumus, kurang teliti dalam angka-angka. Salah satu materi matematika yang dipelajari yaitu geometri.

Menurut Ulum, Budiarto, \& Ekawati, geometri merupakan salah satu materi matematika yang tidak memfokuskan bilangan meskipun materinya mengandung suatu bilangan, tetapi geometri mempelajari hubungan antara titik, garis, sudut, bidang, bangun datar, dan bangun ruang ${ }^{1}$. Geometri yang diajarkan di beberapa sekolah sangat penting karena banyak konsep-konsep yang harus dipelajari. Konsep geometri yang diajarkan pada kelas 3 banyak macamnya yaitu bangun datar (persegi, persegi panjang, dan segitiga), bangun ruang (balok dan kubus), simetri, dan pencerminan. Penjelasan konsep-konsep geometri yang terdapat dalam suatu kebudayaan dapat memberikan pengetahuan serta pengalaman baru. Pengetahuan ini tidak hanya mengenalkan budaya daerah setempat, tetapi dapat membantu siswa

${ }^{1}$ Ulum, B., Budiarto, M. T., \& Ekawati, R. Etnomatematika Pasuruan: Eksplorasi Geometri untuk Sekolah Dasar pada Motif Batik Pasedahan Suropati. Jurnal Kajian Pendidikan dan Hasil Penelitian, Vol. 4, No. 2, (2018.). 
memahami konsep-konsep matematika yang sudah ada dalam kehidupan sehari-hari.

Proses pembelajaran matematika yang diajarkan di sekolah seringkali terlihat konstan dan cara mengajarkannya dominan menggunakan metode ceramah. Hal ini dapat mengakibatkan siswa menjadi bosan, sehingga materi tidak dapat tersampaikan dengan baik, karena tidak ada timbal balik bagi siswa untuk berpikir. Pembelajaran matematika pada umumnya yaitu memberikan rumus kepada siswa kemudian menghafal rumus tersebut tanpa tahu darimana asalnya serta kegunaannya untuk apa. Hal ini akan mengakibatkan siswa kesulitan mempelajari matematika apabila menemukan permasalahan yang harus diselesaikan. Faktor lain yang menyebabkan siswa susah memahami matematika adalah materi pada buku siswa yang kurang lengkap pada kurikulum 2013, sehingga siswa kurang mendapatkan pemahaman materi dalam mempelajari matematika.

Berdasarkan paparan tersebut, maka perlu adanya inovasi sumber belajar alternatif agar semakin memperkaya pengetahuan dan mencegah rasa bosan siswa saat mengikuti pembelajaran matematika. Sumber belajar adalah semua sumber seperti pesan, orang, bahan, alat, teknik, dan latar yang dimanfaatkan peserta didik sebagai sumber untuk kegiatan belajar dan dapat meningkatkan kualitas belajarnya ${ }^{2}$. Hafid menyatakan bahwa sumber belajar adalah sesuatu yang dapat mengandung pesan untuk disajikan melalui penggunaan alat ataupun oleh dirinya sendiri dapat pula merupakan segala sesuatu yang digunakan untuk menyampaikan pesan yang tersimpan di dalam bahan pembelajaran yang akan diberikan ${ }^{3}$.

Pada dasarnya anak-anak usia sekolah dasar (SD) masih suka bermain dengan memanfaatkan interaksi di lingkungan sebagai sumber belajarnya. Siswa usia SD memasuki tahap operasional konkret, yaitu pembelajaran

${ }^{2}$ Abdullah, R, Pembelajaran Berbasis Pemanfaatan Sumber Belajar, Jurnal Ilmiah DIDAKTIKA, Vol. 12, No. 2, (2012).

${ }^{3}$ Hafid, H. A, Sumber dan Media Pembelajaran, Jurnal Pendidikan Agama Islam, Vol. 6, No. 11, (2011). 
yang didampingi dengan benda konkret. Oleh karena itu, karakteristik siswa SD dapat digunakan sebagai inovasi dengan memasukkan unsur kebudayaan lokal tertentu ke dalam materi matematika sebagai suatu inovasi untuk memperkaya sumber belajar mereka. Guru mengajarkan materi matematika sambil bermain, sehingga anak-anak tanpa sadar telah mempelajari materi matematika. Materi yang diterima akan terus diingat, karena kondisi belajar yang menyenangkan, bermakna, serta menarik akan lebih bertahan lama dalam ingatan siswa.

Inovasi untuk memperkaya sumber belajar dapat dituangkan dalam bentuk pembelajaran matematika berbasis kebudayaan, karena budaya dan matematika saling berkaitan untuk diterapkan dalam kehidupan sehari-hari. Menurut Safitri, Sugiarti, \& Hutama, pembelajaran matematika menyajikan lambang-lambang yang mempunyai fungsi serta beberapa pola yang sering menyerupai objek-objek disekitar ${ }^{4}$. Melalui budaya lokal diharapkan siswa lebih termotivasi dan menjadikan matematika lebih menarik, serta untuk mencapai tujuan pembelajaran guru membutuhkan inovasi baru berbasis budaya lokal agar siswa lebih familiar terhadap materi. Matematika dan budaya merupakan kesatuan yang erat kaitannya jika diterapkan di kehidupan sehari-hari. Matematika merupakan ilmu pengetahuan pasti, sehingga dapat digunakan untuk memecahkan masalah sehari-hari. Budaya merupakan hasil olah pikiran masyarakat setempat yang mengatur seluruh aspek masyarakat tersebut. Unsur kebudayaan yang diadaptasi ke dalam mata pelajaran matematika disebut juga sebagai etnomatematika.

Etnomatematika merupakan inovasi baru di dalam ilmu matematika yang menjelaskan bagaimana muatan matematika diperoleh dari suatu budaya $^{5}$. Etnomatematika merupakan pembelajaran matematika yang

\footnotetext{
${ }^{4}$ Safitri, F. A., Sugiarti, T., \& Hutama, F. S, Analisis Kesalahan Siswa dalam Menyelesaikan Soal Cerita Bangun Datar Berdasarkan Newman's Error Analysis (NEA). Jurnal Profesi Keguruan, Vol. 5, No. 1, (2019).

${ }^{5}$ Hardiarti, S. Etnomatematika: Aplikasi Bangun Datar Segiempat pada Candi Muaro Jambi. Aksioma, Vol. 8, No. 2, (2017).
} 
tumbuh dan berkembang sesuai dengan budaya daerah tertentu dan digunakan sebagai proses pembelajaran dan metode pengajaran ${ }^{6,7}$. Penerapan etnomatematika pada siswa harus didukung oleh guru yang dapat memahami nilai-nilai budaya, agar siswa tidak salah mengerti dalam menerima materi. Khofifah dkk, menyatakan bahwa, guru harus memahami ilmu tradisi atau kebudayaan dari daerah tertentu dan menganalisis hubungannyadengan unsur matematika agar dapat menyampaikan pembelajaran etnomatematika ${ }^{8}$. Etnomatematika dari hasil kebudayaan di Indonesia misalnya bentuk rumah adat, kesenian, motif kain batik, ukiran serta bangunan bersejarah.

Unsur kebudayaan yang digunakan dalam materi matematika diharapkan dapat membuat siswa memperoleh pengalaman baru serta berinteraksi dengan dunia luar dalam mempelajari matematika. Penggunaan pembelajaran berbasis etnomatematika ini, dapat membuat anak-anak lebih mudah memahami dan mengingat konsep matematika tanpa harus menghafal rumus, karena pembelajarannya menggunakan konsep-konsep budaya lokal. Budaya sangat berpengaruh terhadap pemahaman siswa, karena apabila budaya yang diadaptasi ke dalam matematika sangat asing bagi siswa, maka siswa akan sulit menerima materi. Oleh karena itu, perlu adanya suatu pendekatan yang baru untuk membantu proses belajar agar mampu menghubungkan antara matematika dengan budaya. Salah satu objek etnomatematika yang banyak dijumpai anak-anak yaitu pada bangunan candi. Candi terdapat konsep etnomatematika yang dapat diterapkan ke dalam pembelajaran matematika.

\footnotetext{
${ }^{6}$ Marsigit., Condromukti, R., Setiana, D. S., Hardiarti, S. Pengembangan Pembelajaran Matematika Berbasis Etnomatematika. Prosiding Seminar Nasional Etnomatnesia, 2015).

${ }^{7}$ Wahyuni, A., Tias, A. \& A. W., Sani, B, Peran Etnomatematika dalam Membangun Karakter Bangsa. (Seminar Nasional Matematika dan Pendidikan Matematika, Yogyakarta: 9 November, (2013).

${ }^{8}$ Khofifah, L., Sugiarti, T., \& Setiawan, B. S. Etnomatematika Karya Seni Batik Khas Suku Osing Banyuwangi sebagai Bahan Lembar Kerja Siswa Materi Geometri Transformasi. Jurnal Matematika dan Pendidikan Matematika, Vol. 9, No. 3, (2018).
} 
Candi di Indonesia merupakan peninggalan kerajaan Hindu-Budha. Menurut Arifin, candi merupakan bangunan masa lampau yang dibuat oleh raja-raja untuk dimanfaatkan sebagai tempat ibadah atau tempat pemakaman abu jenazah ${ }^{9}$. Fungsi tersebut sesuai dengan arti Candi yang berasal dari kata Candika Ghra yang berarti rumah dewi maut ${ }^{10}$. Keberadaan candi sangat penting pada zaman dahulu, karena digunakan sebagai tempat ibadah untuk memuja dewa-dewi pada agama Hindu serta pemujaan terhadap Budha pada agama Budha. Penyebaran candi di Indonesia banyak sekali, karena pada masa kerajaan kuno bangsa Indonesia sudah banyak membuat candi. Bagian-bagian candi memiliki struktur yang dapat dijadikan sebagai objek matematika yang dapat digunakan sebagai bahan ajar. Objek-objek matematika yang bisa digunakan yaitu bentuk dan ukiran pada candi. Candi yang digunakan sebagai objek penelitian adalah Candi Selogending yang berada di Situs Kandangan, Kecamatan Senduro, Kabupaten Lumajang.

Berdasarkan latar belakang yang telah diuraikan, tujuan penelitian ini adalah menganalisis muatan etnomatematika pada candi Selogending di Kandangan sebagai bahan ajar matematika kelas 4 sekolah dasar.

\section{METODE PENELITIAN}

Jenis penelitian ini menggunakan penelitian kualitatif. Penelitian ini dimaksudkan untuk menganalisis konsep-konsep matematika yang terdapat pada Candi Selogending. Menurut Gunawan, penelitian kualitatif adalah metode penelitian yang bertujuan untuk mendapatkan pengetahuan tentang masalah-masalah sosial ${ }^{11}$. Penelitian ini dimaksudkan untuk menganalisis konsep-konsep matematika yang terdapat pada Candi Selogending.

Lokasi penelitian yang dimaksud adalah Candi Selogending yang terletak di Dusun Selogending, Desa Kandangan, Kecamatan Senduro,

${ }^{9}$ Arifin, F. Representasi Simbol Candi Hindu dalam Kehidupan Manusia: Kajian Linguistik Antropologis. Jurnal Penelitian Humaniora, Vol. 16, No. 2, (2015),

${ }^{10}$ Prasetyo, E. H., \& Suprijono. A. Anasir-Anasir Esoterisme pada Situs Candi Cetho. Jurnal Pendidikan Sejarah, Vol. 2, No. 1, (2014).

${ }^{11}$ Gunawan, I, Metode Penelitian Kualitatif Teori \& Praktik, (Jakarta: Bumi Aksara. 2014). 
Kabupaten Lumajang, Provinsi Jawa Timur. Pengambilan daerah penelitian tersebut dilakukan dengan adanya pertimbangan bahwa bagian-bagian pada bangunan Candi Selogending memiliki unsur-unsur matematika di dalamnya, misalnya pada gapura pintu masuk candi memenuhi unsur-unsur matematika serta bangunan-bangunan lainnya.

Subjek penelitian adalah orang atau narasumber yang memberikan informasi mengenai objek penelitian. Subjek penelitian yang digunakan adalah (1) sesepuh yang sudah tinggal lama di Desa Kandangan yang mengerti sejarah terbentuknya candi, (2) Tokoh agama yang mengetahui mengenai aturan-aturan pembuatan candi dan mengetahui nama beserta fungsinya dari setiap bangunan, serta (3) tukang bangunan yang ahli dalam pembuatan candi.

Penelitian ini menggunakan metode pengumpulan data observasi, wawancara, dan dokumentasi.Observasi dilakukan sebagai pengamat yang membatasi dirinya sebagai observer dan narasumber sebagai objek pengamatan, sehingga pengamat membatasi kegiatannya dalam berbaur dengan narasumber. Kegiatan observasi dilakukan dengan bantuan pedoman observasi berisi hal-hal yang digunakan untuk pengamatan kemudian akan dilanjutkan dengan mencatat hasil observasi. Pedoman observasi yang digunakan telah divalidasi dan dinyatakan layak oleh para ahli yang memvalidasi yaitu 3 Dosen PGSD yang ahli dalam bidang materi matematika SD. Sedangkan, wawancara dalam penelitian ini bertujuan untuk mendapatkan informasi subjek penelitian. Metode wawancara yang digunakan adalah wawancara semiterstruktur yaitu melakukan kegiatan wawancara dengan topik yang sudah dipersiapkan pada pedoman wawancara. Wawancara dilakukan dengan narasumber sesuai dengan pedoman wawancara, tetapi pertanyaan dapat dikembangkan ataupun dapat juga memunculkan pertanyaan baru jika terdapat pertanyaan yang perlu ditanyakan selama proses wawancara. Wawancara dilakukan dengan bantuan instrumen pedoman wawancara yang berisi daftar pertanyaan yang 
diperlukan untuk menggali informasi tentang muatan etnomatematika pada objek yang diteliti.Instrumen pedoman wawancara yang digunakan telah divalidasi sebelumnya dan dinyatakan layak untuk digunakan dalam penelitian. Metode dokumentasi digunakan untuk mengumpulkan data berupa foto atau gambar Candi Selogending yang memuat unsur-unsur etnomatematika.

Data hasil observasi dan wawancara yang didapat dalam penelitian ini diuji keabsahannya menggunakan teknik triangulasi data. Triangulasi data yang digunakan terdiri dari dua jenis yaitu triangulasi sumber dan triangulasi waktu. Triangulasi sumber dilakukan untuk mengecek keabsahan atau kebenaran data dengan mengkonfirmasi data yang didapat dari suatu sumber pada sumber lain. Sedangkan Triangulasi waktu dilakukan dengan mengecek data yang didapat sebelumnya dengan mengkonfirmasinya pada waktu yang berbeda (dilakukan konfirmasiulang data yang diperoleh pada hari selanjutnya).

Tahapan analisis data dalam penelitian ini menggunakan analisis data kualitatif meliputi:(1) reduksi data, memuat kegiatan meringkas, memperjelas, dan mengkategorikan data yang terkumpul agar lebih berfokus pada etnomatematika yang terdapat pada Candi Selogending; (2) pemaparan data, terdiri dari kegiatan menyajikan data, menganalisis, dan menghubungkan data muatan etnomatematika yang diperoleh agar dapat disusun suatu kesimpulan; dan (3) penarikan kesimpulan, dilakukan dengan menyimpulkan hasil temuan berdasarkan kajian dan pemaparan data temuan etnomatematika.

\section{HASIL DAN PEMBAHASAN TEMUAN}

Hasil dari penelitian yang telah dilakukan memuat bentuk serta ukiran pada Candi Selogending yang didapatkan dari observasi, wawancara serta dokumentasi berupa foto. Observasi dilakukan di Situs Selogending Desa Kandangan, Kecamatan Senduro, Kabupaten Lumajang. Wawancara dilakukan pada narasumber yang terdiri dari Tokoh Agama Hindu, Tukang 
Bangunan, serta Tukang Pembuat Sketsa untuk mendapatkan informasi lebih lanjut. Data hasil penelitian yang diperoleh kemudian dianalisis secara deskriptif kemudian dikaitkan dengan materi matematika yang sesuai dengan kurikulum yang berlakusebagai tambahan sumber belajar matematika.

Candi Selogending merupakan kawasan Candi yang terbuat dari batu yang digunakan untuk bertapa umat Hindu. Kemudian kawasan ini hilang, karena banyak sekali benda-benda di dalamnya tertimbun tanah. Tahun 2010 ditemukan pondasi dari kawasan Candi ini, kemudian dibangun kembali kawasan tersebut, sehingga lebih terawat. Kawasan Candi Selogending ini memiliki 5 bangunan utama yaitu Mbah Tejo Kusumo, Mbah Pukulun, Wadung Prabu, Linggasiwa dan Mbah Raden Selogending. 5 bangunan tersebut digunakan oleh warga Hindu untuk melakukan pemujaan kepada dewa. Selain itu, bangunan lainnya juga ada di kawasan tersebut aantara lain bangunan sanggah yang terdiri dari 5 bangunan yaitu Mpu Gana, Mpu Gnijaya, Mpu Kutura, Mpu Brada dan Mpu Semeru yang melambangkan tempat perkumpulan leluhur pada zaman dahulu. Bangunan lainnya yaitu Tempat Pemujaan, Balai Patrapan, Padma, dan Gapura Pintu Masuk merupakan bangunan tambahan di kawasan tersebut.Berdasarkan hasil observasi dan wawancara pada Candi Selogending, ditemukan beberapa bentuk yang memiliki etnomatematika di dalamnya. Terdapat beberapa bangunan yang memiliki konsep etnomatematika.

Gapura pintu masuk Candi merupakan bangunan yang terdiri dari 3 bagian yaitu kepala gapura, badan gapura serta kaki gapura. Kepala gapura terdiri dari 3 lapisan yang semakin ke depan akan semakin kecil ukurannya serta pada bagian puncak gapura berbentuk segitiga. 


\section{Gambar 1. Gapura Pintu Masuk Candi Selogending}

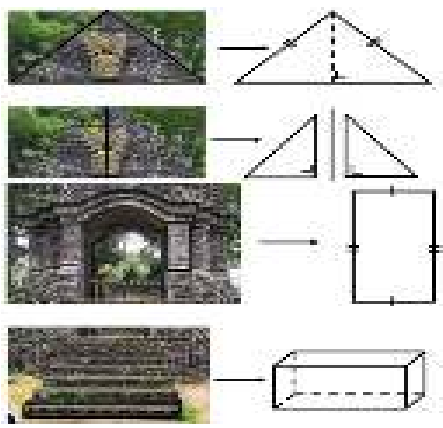

Berdasarkan hasil observasi terdapat bentuk persegi panjang yang semakin ke atas akan semakin kecil ukurannya. Bangunan ini berbentuk 3 dimensi, sehingga dapat dikatakan pada kepala gapura terdapat konsep balok, karena memiliki volume. Kemudian pada badan gapura terdiri dari tiang gapura yang sama antara kanan dan kiri. Terdapat konsep matematika yaitu bangun datar persegi panjang dan bangun ruang balok serta pencerminan, karena bagian kanan dan kiri bentuknya sama. Bentuk dan ukiran pada gapura didapatkan dari pondasi bangunan yang ditemukan. Kemudian pembuat sketsa bangunan akan menggambar sesuai imajinasi yang berpatokan pada pondasi. Ukuran yang digunakan oleh tukang bangunan menggunakan benang yang diikatkan ke kayu sebagai patokan. Hal ini bertujuan untuk mengukur panjang dan lebarnya agar sama. Ukuran batu yang digunakan pun harus sama satu sama lain. Muatan etnomatematika lain terdapat pada bangunan makam "Mbah Tejo Kusumo".

\section{Gambar 2. Bangunan Mbah Tejo Kusumo}

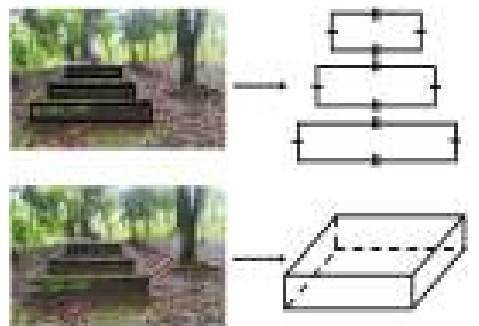

Bentuk bangunan "Mbah Tejo Kusumo" ini memiliki alas berbentuk persegi panjang, bangunan yang menjadi alas berbentuk balok bertingkat. Balok bertingkat tersebut terdiri dari 3 tingkat. Puncak dari bangunan 
terdapat batu tertancap di tanah yang dikeramatkan. Pembuat sketsa bangunan menggambar bangunan ini mengacu pada simbol Trimurti dalam agama Hindu yang mengagungkan 3 dewa yaitu Brahmana, Wisnu dan Siwa. Jadi tingkatan 3 tersebut merupakan simbol Trimurti.Berdasarkan hasil observasi pada bangunan Mbah Tejo Kusumo, terdapat bentuk yang memiliki konsep matematika yaitu pada sisi bangunan terdapat konsep bangun datar persegi panjang. Bangunan bertingkat juga terdapat konsep matematika bangun ruang balok, karena memiliki volume. Fungsi bangunan ini adalah sebagai tempat pemujaan. Bangunan lain yang memiliki unsur etnomatematika adalah "Mbah Pukulan".

\section{Gambar 3. Bangunan Mbah Pukulan}

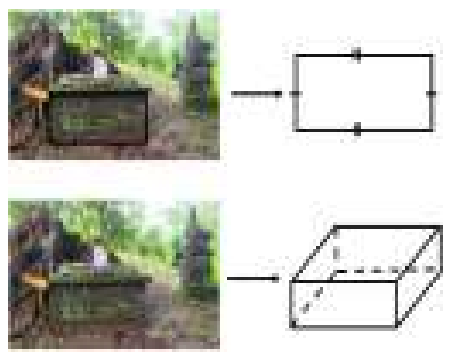

Bangunan "Mbah Pukulun" yang memiliki konsep bangunan lebih sederhana seperti meja. Alas pada bangunan ini berbentuk persegi panjang, bangunan ini memiliki volume, sehingga dapat dikatakan terdapat konsep bangun ruang balok. Bagian atas bangunan terdapat batu keramat yang ditancapkan ke atas. Tempat ini digunakan untuk tempat pemujaan. Pembuatan Mbah Pukulun didasarkan pada pondasi yang ditemukan. Jadi pembuat sketsa akan menggambar bangunan tersebut sesuai dengan pondasi, kemudian bagian lainnya sesuai dengan imajinasi. Bangunan ini tidak terdapat ukiran-ukiran khas Hindu. Penentuan ukuran masih terbilang tradisional yaitu dengan mengikatkan benang pada kayu sebagai patokan untuk menentukan panjang dan lebarnya. Selain "Mbah Pukulan", unsur matematika terdapat pada bangunan "Balai Patrapan”. 


\section{Gambar 4. Bangunan Balai Patrapan}

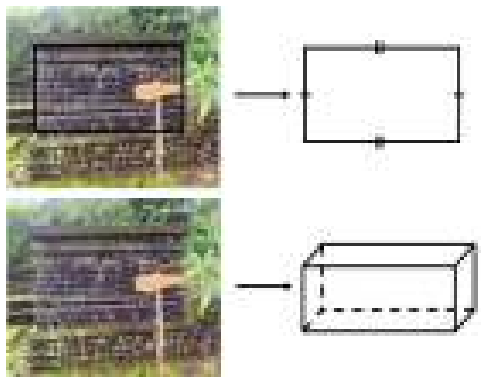

Pembuatan balai ini memiliki konsep yang sama dengan Petilasan Mbah Pukulun yang bisa digunakan sehari-hari yaitu konsep untuk meletakkan sesuatu. Konsep bentuk Balai Patrapan hampir sama dengan Mbah Pukulun yang memiliki alas berbentuk persegi panjang. Berdasarkan hasil observasi ditemukan bangun datar persegi panjang dan bangun ruang balok. Bangunan tersebut memiliki volume sehingga dapat dikatakan memiliki konsep bangun ruang balok. Meskipun bangunan ini bukan bangunan utama, tetapi balai ini memiliki fungsi yang digunakan meletakkan sesaji apabila terdapat acara besar keagamaan. Balai ini dua kali lebih tinggi daripada Mbah Pukulun. Unsur etnomatematika selanjutnya terdapat pada bangunan tempat pemujaan.

\section{Gambar 5. Bangunan Tempat Pemujaan}

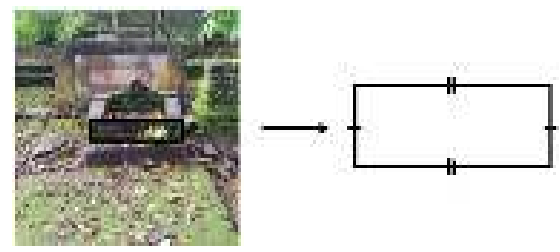

Pondasi tempat ini sudah ada pada zaman dahulu, sehingga tukang yang membangun tempat ini sesuai dengan pondasi terdahulu. Tempat pemujaan ini memiliki bentuk lebih kecil dibandingkan dengan bangunan lainnya. Bangunan ini berbentuk persegi panjang pada bagian alasnya serta pada bagian atas melengkung di kedua sisinya. Konsep matematika yang terdapat pada bangunan tempat pemujaan antara lain persegi panjang serta 
balok, karena memiliki volume. Bangunan dengan unsur etnomatematika selanjutnya adalah "petilasan Wadung Prabu".

\section{Gambar 6. Bangunan Petilasan Wadung Prabu}

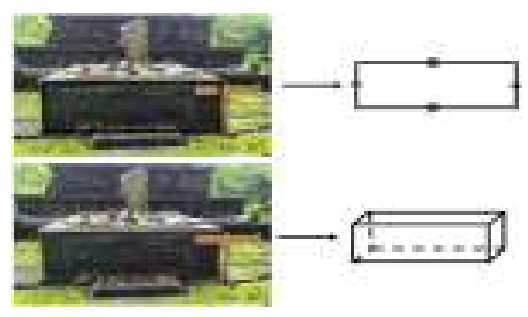

Menurut penjelasan Pemangku Adat, tempat Wadung Prabu ini memiliki filosofi pembangunannya yaitu pada zaman dahulu terdapat orang yang bertapa di daerah tersebut dengan membawa kapak. Tempat tersebut dinamakan Wadung yang artinya kapak serta Prabu artinya Raja. Kemudian tempat tersebut diletakkan di tempat tertinggi serta senjata kapak tersebut ditanamkan disebuah kotak. Bangunan Petilasan Wadung Prabu memuat konsep matematika bangun datar persegi panjang serta bangun ruang balok, karena memiliki volume. Bangunan lain yang memiliki unsur etnomatematika adalah "Padma".

\section{Gambar 7. Bangunan Padma}

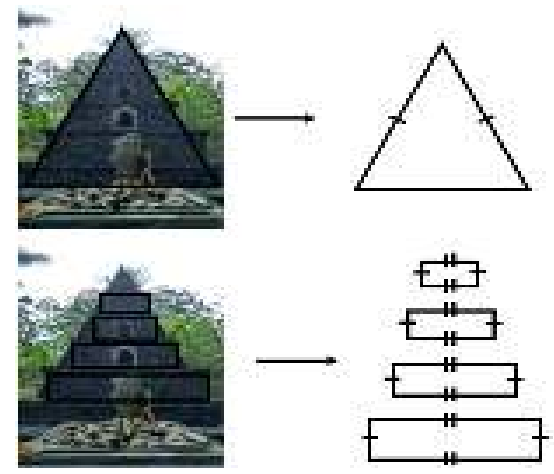

Menurut penjelasan Pemangku Adat, "Padma" berada di belakang Petilasan Wadung Prabu yang memiliki makna tempat singgasana Raja. Ornamen pada bangunan ini dilengkapi dengan patung ular pada bagian bawah yang hampir mengelilingi bangunan. Bangunan Padma memiliki beberapa tingkatan yang semakin ke atas akan semakin kecil. Pada 
bangunan "Padma" terdapat beberapa konsep matematika pada bangunan Padma yaitu berbentuk segitiga sama kaki pada sisi belakang bangunan, serta pada bagian depan terdapat bentuk persegi panjang dan balok, karena memiliki volume. Setiap tingkatan terdapat ormanen seperti jendela yang menyerupai bentuk setengah lingkaran. Unsur etnomatematika selanjutnya terdapat pada bangunan "Petilasan Mbah Raden Selogending".

\section{Gambar 8. Bangunan Petilasan Raden Selogending}

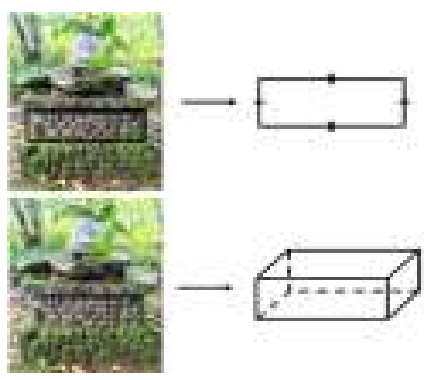

Petilasan ini berada paling ujung pada kawasan Situs Selogending. Petilasan ini berhubungan dengan Dewa Brahmana yang bertugas menciptakan alam. Berdasarkan hasil observasi ditemukan beberapa konsep matematika yaitu bangun datar persegi panjang yang terdapat pada setiap sisi bangunan, serta bangun ruang balok, karena bentuk petilasan tersebut memiliki volume. Bangunan lain yang memuat unsur matematika adalah "Linggasiwa".

\section{Gambar 9. Bangunan Linggasiwa}

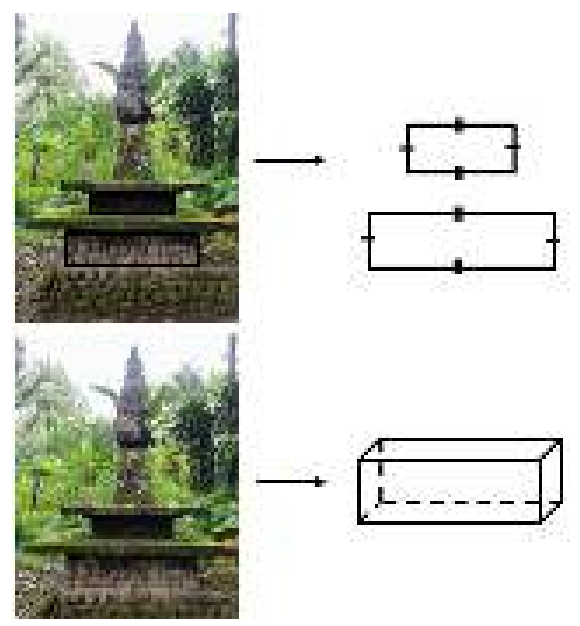


Bentuk bangunan pada Linggasiwa ini memiliki alas yang berbentuk persegi panjang serta memiliki 2 tingkatan. Tingkatan pertama berbentuk balok serta tingkatan kedua berbentuk setengah dari tingkatan pertama. Bentuk tingkatan pertama dan kedua yaitu persegi panjang pada setiap sisinya. Bagian atas bangunan terdapat ukiran dewa-dewa Hindu yang berbentuk lonjong ke atas. Setelah dilakukan observasi dapat diperoleh konsep matematika pada bangunan tersebut antara lain balok, persegi panjang, serta pencerminan.

Hasil penelitian ini menunjukan bahwa terdapat muatan etnomatematika pada bangunan-bangunan dalam situs Candi Selogending. Muatan unsur matematika tersebut meliputi bangun geometri bidang, geometri ruang dan pencerminan. Berdasarkan analisis yang telah dilakukan, muatan etnomatematika pada Bangunan Candi Selogending memiliki potensi untuk dapat dimanfaatkan sebagai sumber ajar bagi siswa kelas IV SD. Temuan penelitian ini menguatkan hasil penelitian lain yang menyatakan bahwa, pada bangunan-bangunan pusat kebudayaan seperti tempat ibadahdan rumah adat memiliki unsur matematika yang dapat dimanfaatkan sebagai sumber belajar alternatif untuk mengajarkan materimateri geometri ${ }^{12,13}$. Sedangkan beberapa penelitian lain menungkapkan bahwa, benda-benda yang berkaitan dengan kebudayaan seperti alat musik dan permainan tradisional memiliki unsur-unsur matematika yang dapat dimanfaatkan dalam pembelajaran ${ }^{14,15,16}$.

${ }^{12}$ Afifi, R. N., dkk. Etnomatematika pada Bangunan Tempat Ibadah Tri Dharma Hoo Tong Bio Berdasarkan Konsep Geometri sebagai Bahan Ajar Siswa, Jurnal Matematika dan Pendidikan Matematika, Vol. 10, No. 1, (2019).

${ }^{13}$ Rosita, S. M., Sunardi., \& Pambudi, D.S, Etnomatematika pada Rumah Adat Osing Banyuwangi sebagai Bahan Ajar Pembelajaran Matematika, Jurnal Matematika dan Pendidikan Matematika, Vol. 1, No. 1, (2019).

${ }^{14}$ Lubis, S. I., Mujib, A., \& Siregar, H. Eksplorasi Etnomatematika pada Alat Musik Gordang Sambilan, Jurnal Riset Pendidikan Matematika, Vol. 1, No. 2, (2018).

${ }^{15}$ Putri, L. I. Eksplorasi Etnomatematika Kesenian Rebana sebagai Sumber Belajar Matematika pada Jenjang MI, Jurnal Ilmiah Pendidikan Dasar, Vol. 4, No. 1, (2017). 
Unsur-unsur matematika dalam hasil kebudayaan masyarakat terdahulu berupa Candi Selogending dapat dimanfaatkan sebagai alternatif sumber belajar matematika siswa. Dalam pembelajaran matematika, guru dapat memanfaatkan bangunan di sekitar wilayah Candi Selogending sebagai media belajar geometri siswa sehingga pembelajaran etnomatematika benar-benar terwujud dengan optimal. Hal tersebut sesuai dengan pendapat Lubis, mujib \& Siregar yang menyatakan bahwa, etnomatematika menekankan pada kegiatan belajar siswa dengan memanfaatkan kondisi budaya yang dimiliki, disatukan dalam pembelajaran berbasis budaya ${ }^{17}$. Menurut Zayyadi, pembelajaran etnomatematika dapat dilakukan dengan integrasi hasil kebudayaan yang berkembang di masyarakat seperti peninggalan budaya berupa candi, prasasti, gerabah, batik, permainan tradisional serta pola pemukiman masyarakat yang dihubungkan dengan konsep matematika ${ }^{18}$. Dengan pengintegrasian etnomatematika dalam pembelajaran, siswa akan mempelajari konsepkonsep matematika secara lebih bermakna sekaligus mengenal berbagai kebudayaan di sekitar mereka. Hal tersebut sesuai dengan penelitian terdahulu yang membuktikan bahwa penerapan etnomatematika dengan budaya-budaya lokal tertentu mampu meningkatkan hasil belajar matematika siswa serta membantu pengenalan kebudayaan disekitar ${ }^{19,20}$.

\footnotetext{
${ }^{16}$ Aprilia, E. D., Trapsilasiwi, D., Setiawan, T. B. Etnomatematika pada Permainan Tradisionsl Engklek Beserta Alatnya sebagai Bahan Ajar. Jurnal Matematika dan Pendidikan Matematika, Vol. 10, No. 1, (2012).

${ }^{17}$ Lubis, S. I., Mujib, A., \& Siregar, H, Loc.Cit.

${ }^{18}$ Zayyadi, M. Eksplorasi Etnomatematika pada Batik Madura. Jurnal Sigma, Vol. 2, No. 2, (2017).

${ }^{19}$ Tandililing, E. Pengembangan Pembelajaran Matematika Sekolah dengan Pendekatan Etnomatematika Berbasis Budaya Lokal sebagai Upaya untuk Meningkatkan Kualitas Pembelajaran Matematika Sekolah. Prosiding Seminar Nasional Matematika dan Pendidikan Matematika, (P-25), (2013).

${ }^{20}$ Irawan, A. Penggunaan Etnomatematika Engklek dalam Pembelajaran Matematika. Jurnal Math Education Nusantara, Vol. 1, No.1, (2018).
} 


\section{SIMPULAN}

Kesimpulan yang dapat diperoleh adalah terdapat muatan etnomatematika pada bangunan-bangunan Candi Selogending. Bangunan yang memiliki unsur muatan etnomatematika adalah bangunan Gapura Pintu Masuk, bangunan Petilasan Mbah Tejo Kusumo, bangunan Petilasan Mbah Pukulun, bangunan Balai Patrapan, tempat pemujaan, bangunan Petilasan Wadung Prabu, bangunan Linggasiwa, dan bangunan Petilasan Mbah Raden Selogending.Muatan unsur matematika tersebut meliputi bangun geometri bidang, geometri ruang dan pencerminan. Muatan etnomatematika yang terdapat pada bangungan-bangunan Candi Selogending dapat digunakan sebagai alternatif sumber belajar dalam muatan matematika di kelas 4 SD. 


\section{DAFTAR PUSTAKA}

Abdullah, R. Pembelajaran Berbasis Pemanfaatan Sumber Belajar. Jurnal Ilmiah DIDAKTIKA, Vol. 12, No. 2, (2012), 216.

Afifi, R. N., dkk. Etnomatematika pada Bangunan Tempat Ibadah Tri Dharma Hoo Tong Bio Berdasarkan Konsep Geometri sebagai Bahan Ajar Siswa. Jurnal Matematika dan Pendidikan Matematika, Vol. 10, No. 1, (2019), 25.

Aprilia, E. D., Trapsilasiwi, D., Setiawan, T. B. Etnomatematika pada Permainan Tradisionsl Engklek Beserta Alatnya sebagai Bahan Ajar. Jurnal Matematika dan Pendidikan Matematika, Vol. 10, No. 1, (2012), 85.

Arifin, F. Representasi Simbol Candi Hindu dalam Kehidupan Manusia: Kajian Linguistik Antropologis. Jurnal Penelitian Humaniora,Vol. 16 No. 2 (2015), 12.

Gunawan, I. Metode Penelitian Kualitatif Teori \& Praktik. Jakarta: Bumi Aksara.2014.

Hafid, H. A. Sumber dan Media Pembelajaran. Jurnal Pendidikan Agama Islam, Vol. 6, No. 11, (2011), 69.

Hardiarti, S. Etnomatematika: Aplikasi Bangun Datar Segiempat pada Candi Muaro Jambi. Aksioma, Vol. 8, No. 2, (2017), 99. https://bit.ly/2pLaaeX.

Irawan, A. Penggunaan Etnomatematika Engklek dalam Pembelajaran Matematika. Jurnal Math Education Nusantara,Vol. 1, No.1, (2018), 46.

Khofifah, L., Sugiarti, T., \& Setiwan, B. S. Etnomatematika Karya Seni Batik Khas Suku Osing Banyuwangi sebagai Bahan Lembar Kerja Siswa Materi Geometri Transformasi. Jurnal Matematika dan Pendidikan Matematika, Vol. 9, No. 3, (2018), 148.

Lubis, S. I., Mujib, A., \& Siregar, H. Eksplorasi Etnomatematika pada Alat Musik Gordang Sambilan. Jurnal Riset Pendidikan Matematika, Vol. 1, No. 2, (2018), 10.

Marsigit., Condromukti, R., Setiana, D. S., Hardiarti, S. Pengembangan Pembelajaran Matematika Berbasis Etnomatematika. Prosiding Seminar Nasional Etnomatnesia,(2015).

Putri, L. I. Eksplorasi Etnomatematika Kesenian Rebana sebagai Sumber Belajar Matematika pada Jenjang MI. Jurnal Ilmiah Pendidikan Dasar, Vol. 4 No. 1, (2017), 21. 
Prasetyo, E. H.,\& Suprijono. A. Anasir-Anasir Esoterisme pada Situs Candi Cetho. Jurnal Pendidikan Sejarah, Vol. 2, No. 1, (2014), 1.

Rosita, S. M., Sunardi., \& Pambudi, D.S. Etnomatematika pada Rumah Adat Osing Banyuwangi sebagai Bahan Ajar Pembelajaran Matematika. Jurnal Matematika dan Pendidikan Matematika, Vol. 1, No. 1, (2019).

Safitri, F. A., Sugiarti, T., \& Hutama, F. S. Analisis Kesalahan Siswa dalam Menyelesaikan Soal Cerita Bangun Datar Berdasarkan Newman's Error Analysis (NEA). Jurnal Profesi Keguruan, Vol. 5, No. 1, (2019), 42.

Tandililing, E. Pengembangan Pembelajaran Matematika Sekolah dengan Pendekatan Etnomatematika Berbasis Budaya Lokal sebagai Upaya untuk Meningkatkan Kualitas Pembelajaran Matematika Sekolah. Prosiding Seminar Nasional Matematika dan Pendidikan Matematika, (P-25),(2013), 193.

Ulum, B., Budiarto, M. T., \& Ekawati, R. Etnomatematika Pasuruan: Eksplorasi Geometri untuk Sekolah Dasar pada Motif Batik Pasedahan Suropati. Jurnal Kajian Pendidikan dan Hasil Penelitian,Vol. 4, No. 2, (2018.), 78.

Wahyuni, A., Tias, A. \& A. W., Sani, B. Peran Etnomatematika dalam Membangun Karakter Bangsa. Seminar Nasional Matematika dan Pendidikan Matematika, Yogyakarta: 9 November, (2013).

Zayyadi, M. Eksplorasi Etnomatematika pada Batik Madura. Jurnal Sigma,Vol. 2, No.2, (2017), 35. 